\title{
Correlation between ffp transfusion and length of stay in icu patients
}

\author{
A Vakalos ${ }^{*}$, I Nikitidis \\ From ESICM LIVES 2015 \\ Berlin, Germany. 3-7 October 2015
}

\section{Introduction}

While plasma donation is still necessary as a unique source of human proteins and to treat coagulation disorders, FFP administration seems to have high rate of inappropriate indication. After all, FFP transfusion is not risk free, and is associated with lung injury, infectious disease and circulatory overload in recipients. On the other hand, patients required long ICU hospitalization, may have impaired physical status and increased demand for FFP transfusion.

\section{Objectives}

The aim of our retrospective observation study was to test the hypothesis that a correlation exists between FFP transfusion and length of ICU stay (LOS), in our both medical and surgical ICU served in community hospital.

\section{Methods}

From January 2006 to June 2014 admitted to our ICU 620 patients, mean age 64.8 years, mean length of ICU stay (LOS) 14.2 days, mean mechanical ventilation duration per ventilated patient (V. Days) 12.23 days, mean
APACHE II score on admission 21.2, predicted mortality $38.9 \%$, actual mortality $31.45 \%$, Standardized Mortality Ratio (SMR) 0.80. From our database we looked for LOS and the following values and indexes according FFP transfusion per year from 2006 to 2014 (mean values). Total, per patient, per hospitalization days (HD), per patient under mechanical ventilation (pts V) and per ventilation days (VD) Using linear correlation method, we looked for linear slope, correlation coefficient $(r)$, and coefficient of determination ( $\mathrm{r} 2$ ), and by linear regression method using ANOVA test we looked for $\mathrm{p}$ value, according LOS. and FFP transfusion.

\section{Results}

\section{Conclusions}

According to our data, there was no statistically significant correlation detected between LOS and FFP transfusion indexes. Our data suggest that even though some patients who require long ICU hospitalization may need more FFP than others, FFP transfused do not correlate statistically significant with LOS in ICU patients.

Table 1 Correlation between LOS and FFP transfusion.

\begin{tabular}{|c|c|c|c|c|c|c|c|}
\hline FFP & Slope & $r$ & $r 2$ & S. Error & Lower C.I. & Upper C.I. & $p$ value \\
\hline Total & -0.0011 & -0.0035 & 3.227 & 0.596 & -15.66 & 15.53 & 0.9929 \\
\hline Per patient & 0.0767 & 0.2599 & 0.0675 & 0.107 & -0.146 & 0.3316 & 0.7994 \\
\hline Per Hosp Day & -0.001 & -0.060 & 0.0036 & 0.008 & -0.021 & 0.0189 & 0.8966 \\
\hline Per pt ventilated & 0.0634 & 0.2039 & 0.0415 & 0.1151 & -0.208 & 0.3357 & 0.5988 \\
\hline Per Vent Day & 0.0035 & 0.1158 & 0.0134 & 0.0114 & -0.023 & 0.0306 & 0.7667 \\
\hline
\end{tabular}


doi:10.1186/2197-425X-3-S1-A148

Cite this article as: Vakalos and Nikitidis: Correlation between $\mathrm{ffp}$

transfusion and length of stay in icu patients. Intensive Care Medicine

Experimental 2015 3(Suppl 1):A148.

\section{Submit your manuscript to a SpringerOpen ${ }^{\circ}$ journal and benefit from:}

- Convenient online submission

- Rigorous peer review

- Immediate publication on acceptance

- Open access: articles freely available online

- High visibility within the field

- Retaining the copyright to your article

Submit your next manuscript at $\gg$ springeropen.com 